DR FILOMENA GIULIA SILEO (Orcid ID : 0000-0001-7380-0576)

DR AMAR BHIDE (Orcid ID : 0000-0003-2393-7501)

Article type : Systematic review

\title{
Perinatal outcomes of twin pregnancies complicated by late twin-twin transfusion syndrome: a systematic review and meta-analysis
}

Filomena Giulia SILEO ${ }^{1,2,3}$, Francesco D’ANTONIO ${ }^{4}$, Can BENLIOGLU ${ }^{1}$, Amar BHIDE $^{1}$, Asma KHALIL ${ }^{1,5,6}$

${ }^{1}$ Fetal Medicine Unit, St George's Hospital, St George's University of London, London, UK

${ }^{2}$ Department of Biomedical, Metabolic and Neural Sciences, International Doctorate School in Clinical and Experimental Medicine, University of Modena and Reggio Emilia, Modena, Italy

${ }^{3}$ Unit of Obstetrics and Gynecology, Azienda Unità Sanitaria Locale - IRCCS, Reggio Emilia, Italy

4Prenatal Medicine Unit, Obstetrics and Gynecology Unit, University "G. d'Annunzio" of Chieti, Chieti, Italy

${ }^{5}$ Vascular Biology Research Centre, Molecular and Clinical Sciences Research Institute, St

George's University of London, London, UK.

${ }^{6}$ Twins Trust Centre for Research and Clinical Excellence, St George's Hospital, London, UK

\section{Corresponding Author:}

Asma Khalil

Fetal Medicine Unit, Department of Obstetrics and Gynaecology, St. George's University

Hospitals NHS Foundation Trust, Blackshaw Road, London, SW17 0QT, UK

This article has been accepted for publication and undergone full peer review but has not been through the copyediting, typesetting, pagination and proofreading process, which may lead to differences between this version and the Version of Record. Please cite this article as doi: 10.1111/AOGS.14066

This article is protected by copyright. All rights reserved 


\section{ABSTRACT}

Introduction: Untreated Twin-to-twin transfusion syndrome (TTTS) is associated with a high risk of perinatal mortality and morbidity. Laser surgery is recommended before 26 weeks' gestation. However, the optimal management in case of late (occurring $>26$ weeks) TTTS is yet to be established.

Material and methods: We conducted a systematic review and meta-analysis to evaluate the outcomes of monochorionic diamniotic twin pregnancies complicated by late TTTS according to different management options (expectant, laser therapy, amnioreduction or delivery). The primary outcome was mortality, including single and double intrauterine, neonatal and perinatal death. Secondary outcomes were composite morbidity, neuromorbidity, respiratory distress syndrome, admission to neonatal intensive care unit, intact survival (i.e. free from neurological complications) and preterm birth $<32$ weeks' gestation. Outcomes were reviewed according to the management and reported for the overall population of twins and disease status (i.e. donor and recipient separately). Random-effect meta-analyses of proportions were used to analyse the data. Results: Nine studies including 796 twin pregnancies affected by TTTS were included. No randomized-controlled trials were available for inclusion. TTTS occurred at $\geq 26$ weeks of gestation in $8.7 \%(95 \%$ CI 6.9-10.9; 67/769) of cases reporting TTTS at all gestation. Intrauterine death occurred in $17.7 \%$ (95\% CI 4.9-36.2) pregnancies managed expectantly, 5.3\% (95\% CI 0.912.9) pregnancies treated with laser and $0 \%(95 \%$ CI $0-9)$ after amnioreduction. Neonatal death occurred in $42.5 \%$ (95\% CI 17.5-69.7) pregnancies managed expectantly, in $2.8 \%$ (95\% CI $0.3-$ 7.7) cases treated with laser and in $20.2 \%$ (95\% CI 6-40) after amnioreduction. Only one study (ten cases) reported data on immediate delivery after diagnosis with no perinatal deaths. Perinatal death incidence was 55.7\% (95\% CI 31.4-78.6) in twin pregnancies managed expectantly, 5.6\% (95\% CI 0.5-15.3) in those treated with laser and 20.2\% (95\% CI 6-40) in those after amnioreduction. Intact survival was reported in $44.4 \%, 96.4 \%$ and $78 \%$ fetuses managed expectantly, with laser or amnioreduction, respectively.

Conclusions: Evidence regarding perinatal mortality and morbidity in twin pregnancies complicated by late TTTS according to the different managements are of very low quality. Therefore further high-quality research in this field is needed to elucidate the optimal management of these pregnancies. 


\section{Key words:}

twin-twin transfusion syndrome; systematic review; twins; amnioreduction. laser; meta-analysis; monochorionic; perinatal mortality
Abbreviations:
CI: Confidence Interval;
IUD: intra-uterine death;
MCDA: monochorionic diamniotic;
NICU: neonatal intensive care unit;
NND: Neonatal death;
NOS: Newcastle-Ottawa Scale;
PND: Perinatal death;
RDS: respiratory distress syndrome;

TTTS: Twin to twin transfusion syndrome

\section{Key message:}

Late TTTS has not an established management yet; available data derives only from small studies of low-quality. Randomized-controlled trials or comparative effectiveness research using the core outcome set for TTTS are needed to elucidate optimal management for these pregnancies. 


\section{INTRODUCTION}

Twin-to-twin transfusion syndrome (TTTS) is the result of a chronic unbalance in intertwin blood volume exchange through the anastomoses present in the placenta of monochorionic twin pregnancies. Its estimated incidence is $10-15 \%$ and if left untreated fetal demise rates approach $90 \%$ with morbidity rates in survivors of over 50\% (1-4). Initially, laser therapy has been offered for TTTS occurring between 16 and 25+6 weeks of gestation because of its invasive and experimental nature (5). Current evidence supports the use of fetoscopic laser photocoagulation of placental anastomoses as first-line treatment in TTTS since it has led to a significant reduction in both perinatal mortality and neurological morbidity. In fact, the overall survival rate is $50-70 \%$ with a risk of abnormal neurodevelopmental outcome ranging between $4 \%$ and $18 \%$ (6-7) 5-6). Moreover, when stratifying monochorionic diamniotic (MCDA) pregnancies according to Quintero staging, the overall survival is higher at earlier Quintero stages (I-II), but perinatal survival rates are reasonable even at stage III and IV when treated with laser therapy (8). Information on TTTS occurring at "unconventional" gestational ages, such as before 16 weeks of after 26 weeks, is scarce. Late TTTS, i.e. TTTS occurring after 26 weeks of gestation, is clinically rare and poses therapeutic dilemmas to the clinicians. In the past, potential maternal risks, technical issues (such as a bigger uterine cavity, larger anastomoses, larger fetuses, etc) restrictions by regulatory agencies and the relative more benign course of TTTS after 26 weeks have been reported as reasons for offering less invasive therapeutic options such as serial amnioreductions and even iatrogenic preterm delivery when viability was reached (9-10). However, both options carry a significant risk of neonatal death and long-term neurological impairment in survivors; in particular, amnioreduction was associated with a $23 \%$ rate of neurological sequelae (11-12) while death and/or severe neurological injury among infants born between 26 and 28 weeks is reported to be around 37\% (13). More than 20 years after the first laser surgery for TTTS, there is good evidence on safety of the procedure (14-16) and therefore several centres are offering laser therapy after 26 weeks but the rarity of late TTTS prevents studies from single centres to draw meaningful conclusions. Despite its importance, there are no robust data yet on the optimal management or on the risk of perinatal mortality and morbidity in late TTTS. Therefore, the aim of this systematic review was to explore the outcome of twin pregnancies complicated by late TTTS. 


\section{MATERIAL AND METHODS}

\section{Protocol, eligibility criteria, information sources and search}

The protocol of this review was designed a priori as recommended for systematic reviews and meta-analysis and registered on PROSPERO database (Registration number CRD42020187261). Medline, Embase, Clinicaltrials.gov and Cochrane Library databases were searched electronically in April 2020, utilizing combinations of the relevant medical subject heading (MeSH) terms, key words, and word variants for "twin pregnancies" and "transfusion" (Supporting Information Table S1). The search and selection criteria were restricted to English language. Reference lists of relevant articles and reviews were hand searched for additional reports. PRISMA (17) and MOOSE (18) guidelines were followed.

\section{Study selection, data collection and data items}

Two authors (FGS and CB) independently reviewed each potentially relevant record based on title and abstract and agreement was reached by consensus. Full texts were retrieved for each potentially relevant citation. Afterwards, full text were reviewed to assess eligibility for inclusion and, using a standardised extraction form, relevant data for the review were independently extracted. Discrepancies between the authors were resolved by discussion with a third author (AK).

In case of overlapping populations across studies, only the report containing the most comprehensive information was included. For those articles in which information was not reported but the methodology was such that this information would have been recorded initially, the authors were contacted.

The inclusion criteria were cohort studies, case series and randomized controlled trials if available, reporting data on outcomes of twin pregnancies affected by late (i.e. after 26 weeks) TTTS. The types of interventions evaluated were: expectant management, i.e. without active interventions such as selective fetoscopic laser or amnioreduction, selective fetoscopic laser ablation of vascular anastomoses, amnioreduction (with or without septostomy), delivery and selective fetal reduction. We excluded studies published before 2000 or including less than 3 cases with late TTTS. The primary outcome was mortality, including:

1) Intra-uterine death (IUD) of either twin, defined as fetal loss after 20 weeks' gestation 
2) Single IUD

3) Double IUD

4) Neonatal death (NND), defined as the death of either twin up to 28 days of life

5) Perinatal death (PND), defined as IUD and NND

6) Live-birth

7) Survival of at least one twin (up to 28 days).

The secondary outcomes were:

1) Overall neonatal morbidity, defined as the presence of at least abnormal brain imaging, respiratory distress syndrome (RDS), admission to the neonatal intensive care unit (NICU) or retinopathy of prematurity (ROP) in either twin

2) Neuromorbidity: defined as the presence of either intra-ventricular haemorrhage (IVH) or periventricular leukomalacia (PVL) of any type on post-natal imaging (ultrasound or magnetic resonance imaging)

3) Severe neuromorbidity, defined as the presence of either severe periventricular leukomalacia (grade III and IV) or periventricular leukomalacia (grade II and III)

4) Respiratory distress syndrome

5) Admission to neonatal intensive care unit (NICU)

6) Intact survival, defined as survival free from neurological complications

7) Preterm birth $<32$ weeks of gestation

\section{Planned sensitivity analysis}

All of these outcomes were explored according to the management adopted (expectant, fetoscopic laser ablation of anastomoses, amnioreduction, selective reduction or delivery), reporting all the explored outcomes in the donor and recipient twin separately. Studies on amnioreduction alone and those on amnioreduction associated with septostomy were considered in the same group since perinatal survival has been reported to be similar with amnioreduction alone and/or septostomy.

\section{Quality assessment}

Quality assessment of the included studies was performed using the Newcastle-Ottawa Scale (NOS) for case-control or cohort studies, judging each study on three broad perspectives: the selection of the study groups; the comparability of the groups and the ascertainment of outcome of 
interest, as previously described (19). According to NOS, a study can be awarded a maximum of one star for each numbered item within the Selection and Outcome categories. A maximum of two stars can be given for Comparability (19).

Case series were evaluated with a modified version of NOS, which is based on 8 questions in the domains of selection, ascertainment, causality and reporting (Supporting Information Table S2); in particular, the overall final judgment was made based on questions 1, 2, 3, 7 and 8, which were deemed most critical in this specific clinical scenario (20).

The quality of evidence on the main outcomes of this systematic review was then judged according to the Grading of Recommendations Assessment, Development and Evaluation (GRADE) system and, based on study limitations, consistency, directness, precision and publication bias, we formulated an overall judgement of quality of evidence for each evaluated outcome (21-22).

\section{Statistical analyses}

We used meta-analyses of proportions to combine data and reported pooled proportion of each outcome in all the pregnancies and then according to the type of management reported. Betweenstudy heterogeneity was explored using the I2 statistic, which represents the percentage of between-study variation that is due to heterogeneity rather than chance. A value of $0 \%$ indicates that no heterogeneity was observed, whereas values $>50 \%$ are associated with substantial heterogeneity. However, due to the clinical heterogeneity among studies, a random effects model was used for all meta-analyses (23). Egger's test was used to assess potential publication bias and funnel plots were created for visual inspection (24). Tests for funnel plot asymmetry were not used when the total number of publications included for each outcome was $<10$, as the tests then lack power to detect real asymmetry (25). The analysis was performed using STATSDIRECT 3.0.171 (StatsDirect Ltd) and REVMAN 5.3 (The Nordic Cochrane Centre, The Cochrane Collaboration, 2014) statistical software.

\section{RESULTS}

\section{General characteristics of the study}


A total of 1799 articles were identified, 292 were assessed with respect to their eligibility for inclusion (Supporting Information Table S3), and 9 studies (14-16,26-31) were included in the systematic review (Table 1; Figure 1). No randomized controlled trials were available for inclusion; data for this review were only derived from non-randomized comparisons $(14,28-30)$ or single-arm series $(15,16,26,27,31)$. These 9 studies included 796 twin pregnancies affected by TTTS. After excluding studies reporting only on late TTTS $(14,26)$, TTTS occurred at $\geq 26$ weeks of gestation in 8.7\% (95\% confidence interval (CI) 6.9-10.9; 67/769). Among the included studies, three reported the outcome of twin pregnancies affected by early TTTS and treated with laser, in one study the management was immediate delivery and in one study they reported amnioreduction. Four studies reported on more than one modality: two on amnioreduction and expectant management, two on laser and amnioreduction.

The results of the quality assessment of the included studies using NOS or its modified version are also presented in Table 1. Most of the included studies scored well at selection, comparability and outcome; all case-series were considered of low quality. Small sample size and retrospective design were the main weakness of the included studies.

\section{Mortality}

The incidence of IUD in late TTTS managed expectantly was $17.7 \%$ (CI 95\% 4.9-36.2) compared to $5.3 \%(95 \%$ CI $0.9-12.9)$ and $0 \%(95 \%$ CI $0-9.0)$ in those treated with laser or amnioreduction, respectively.

The incidence of NND was $42.5 \%$ (95\% CI 17.5-69.7) in expectant management, $2.8 \%$ (95\% CI $0.3-7.7)$ in those treated with laser and 20.2\% (95\% CI 6.0-40) among those having amnioreduction (Table 2).

Overall, the incidence of PND was 55.7\% (95\% CI 31.4-78.6) in expectant management, $5.6 \%$ (95\% CI 0.5-15.3) in pregnancies treated with laser and $20.2 \%$ (95\% CI 6.0-40) in those receiving amnioreduction. Only one study reported on late TTTS managed with immediate delivery after diagnosis (10 fetuses) and no perinatal deaths (IUD + NND) were reported (incidence $0 \%(95 \%$ CI 0-30.8\%)).

Double survival was reported in $21.4 \%$ (95\% CI 3.5-48.8) of the pregnancies managed expectantly, in $85.4 \%$ (95\% CI 71.2-95.4) of pregnancies treated with laser and $73.1 \%$ (95\% CI 44.5-93.9) of those managed with amnioreduction. No survivor was 
recorded in 31.3\% (95\% CI 7.3-62.7), 6.8\% (95\% CI 2.0-14.1) and 17.8\% (95\% CI 2.044.6) of pregnancies managed expectantly, with laser or with amnioreduction, respectively.

\section{Preterm delivery and Neonatal morbidity}

The rates of preterm birth occurring before 32 weeks was $41.2 \%$ (95\% CI 15.8-69.6) in pregnancies managed expectantly, 32.3\% (95\% CI 20.8-45.0) in those treated with laser and $56.4 \%(95 \%$ CI $27.7-83.0)$ in those treated with amnioreduction.

Composite perinatal morbidity, defined as any morbidity as stated before, occurred in $13.6 \%$ fetuses (95\% CI 0.1-44.9) managed expectantly, in 31.9\% (95\% CI 18.3-76.5), 25.9\% (95\% CI $11.0-44.4)$ and $70 \%$ (95\% CI 34.8-93.3) of fetuses managed with laser or amnioreduction or immediate delivery respectively. The incidence of the different morbidities (i.e. neuromorbidity, severe neuromorbidity, respiratory distress syndrome, NICU admission) and intact survival in twins affected by early TTTS according to the management option and disease status (donor vs. recipient) is reported in Table 3; this analysis was challenging and affected by the small number of cases in the included studies.

Intact survival, defined as survival free from neurological complications, was reported in 44.4\% (95\% CI 14.7-76.5) fetuses managed expectantly, although only 17 cases were available for the analysis. The intact survival in twins managed with laser was 96.4\% (95\% CI 89.0-99.8) with 44 twins available for the analysis, 78\% (95\% CI 56.2-93.7) for twins managed with amnioreduction (16 included cases) and 100\% (95\% CI 69.2-100) for delivery (10 included fetuses; 5 twin pregnancies).

The quality of evidence on some clinically relevant outcomes (IUD, NND, PND, no survivor, preterm birth, composite morbidity and intact survival) was judged according to GRADE and resulted to be of very low quality for all of them; the judgements across domains and the overall judgement are presented in Table 4.

\section{DISCUSSION}

This systematic review shows that twin pregnancies affected by late TTTS have an incidence of PND of $55.7 \%$ in expectant management which drops to $20.2 \%$ in those receiving amnioreduction and to $5.6 \%$ in pregnancies treated with laser. Only one study reported on late TTTS managed 
with immediate delivery after diagnosis with no cases of PND (only ten fetuses included) so no meaningful information can be derived from delivery as a possible management for late TTTS.

Composite perinatal morbidity varied from $13.6 \%$ of fetuses managed expectantly to $70 \%$ of fetuses managed with immediate delivery. Intact survival was reported in $44.4 \%$ fetuses managed expectantly, $96.4 \%$ twins managed with laser, $78 \%$ and 100\% twins managed with amnioreduction and delivery, respectively. The quality of the studies included in this systematic review, however, is very low and therefore these results should not be used for counselling, intervention or therapeutic purposes.

This is the first systematic review exploring the outcome of pregnancies complicated by late (i.e. after 26 weeks) TTTS according to management. The main strengths are the multitude of explored outcomes, the accurate literature search, and the stratification of the analysis according to the adopted management and disease status (donor vs. recipient). However, several limitations need to be acknowledged: the small number of cases of the included studies, their retrospective nature and the lack of standardization among studies in both management and surveillance of MCDA pregnancies complicated by late TTTS resulting in an overall very low quality of evidence.

In particular, some of the larger studies published on TTTS express gestational age as mean/median and therefore no information could be retrieved from these papers. In one paper (15), gestational age at treatment was used as a proxy for gestational age at diagnosis and this might constitute a limitation of the review.

The assessment of potential publication bias was also problematic due to the scarce number of individual studies that limits the reliability of formal tests and the nature of the outcomes evaluated that limits the reliability of funnel plots.

Moreover, we could not stratify the analysis according to the ultrasound Quintero staging (32) of the disease since this data was not consistently reported in the included studies; we could not stratify our results according to pregnancy characteristics or placental location; we could only perform a subgroup analysis according to the management and the disease status (when reported) but the very small number of included cases and the small number of events limit the robustness of the results. Moreover, not all the studies reported on all our outcomes, preventing further analysis.

In fact, relevant neonatal outcomes such as neurological, respiratory, gastrointestinal morbidities, early childhood outcomes or long-term follow-up are rarely reported across studies preventing the comparison or the combination of results from different studies and consequently 
preventing the application of results in a clinical context. Finally, we decided to include only papers published after 2000 since older studies are less likely to reflect current management and therapies.

It is likely that neonatal outcomes are nowadays better than those described in the included studies thanks to the improvements in neonatal care of preterm infants; however, we still decided to include all eligible papers published after 2000 and not only more recent studies in order to have a larger number of included studies.

Despite these limitations, the present review represents the most comprehensive published estimate of the investigated outcomes in MCDA twin pregnancies complicated by late TTTS.

TTTS remains one of the main determinants of perinatal outcomes in MCDA pregnancies.

It is uncommon after 26 weeks, and in some cases there might be an earlier onset but delayed diagnosis. The optimal management for these pregnancies is yet to be ascertained (33).

The data on expectant management originates from old papers with few included cases and therefore evidence on this management is of very low quality. In more recent publications (1416,26-28) laser was part of the management of these pregnancies, although in several countries laser is usually reserved to pregnancies between 16 and 26 weeks of gestation (4).

For "conventional" TTTS occurring between 16 and 26 weeks, laser is currently considered as the first line therapy since it changes the natural history of this disease improving survival and morbidity outcomes (34).

In late TTTS, there is no consensus. In fact, the rationale behind offering laser till $25+6$ weeks of gestation was its initially experimental nature (5) and that when reaching fetal viability, less invasive palliative therapies such as amniodrainage should be preferred or even immediate delivery should be considered as an option (35).

At present some fetal medicine centres have started offering laser also beyond 26 weeks in order to improve survival and reduce the risk of neurologic sequelae, as a consequence of hemodynamic disturbances and/or severe prematurity while other centres still propose amnioreduction in order to gain some days and start steroids before delivery. Some cases of brain damages after late amniodrainage have been reported and the "placental steal phenomenon" has been proposed as the pathophysiological explanation: in particular, the amnioreduction could have caused a severe shift in the feto-placental blood volume, leading to acute hypovolemia in the recipient fetus and consequent brain damages $(36,37)$. Despite being a fascinating hypothesis, the 
quality of evidence regarding different managements and late TTTS is very low and therefore no meaningful conclusions can be draw.

Regarding feasibility of laser surgery at late gestation, laser is considered to be more difficult at advanced gestations compared to earlier procedures for several reasons: difficult identification of anastomoses due to the turbidity of the amniotic fluid; wider excursion of movements required because of larger placentas and uterine cavities; larger anastomoses and therefore more difficult to coagulate with a higher risk of hemorrhagic accident (16). However, several studies included in this review reported similar results of "late laser" compared to "conventional laser" procedures $(14-16,26)$, therefore, suggesting a re-evaluation of its conventional gestational age limits.

The ascertainment of morbidity outcomes in MCDA complicated by late TTTS was challenging due to the wide heterogeneity among studies in defining the outcomes, postnatal assessment and length of follow up. Moreover, the majority of these published studies focused on mortality. However, as there is an improvement in survival and neonatal cares, the researches should be encouraged to focus on short and long-term morbidities and to use the recently published core outcome set in TTTS in order to improve the quality of reporting future studies (38).

\section{CONCLUSION}

MCDA twin pregnancies complicated by late TTTS have an increased risk of perinatal mortality and morbidity. This meta-analysis reports on the key mortality and morbidity outcomes in these pregnancies according to the management or therapy received. However, the small number of included cases, the heterogeneity in reporting and defining outcomes and follow-up among studies prevent us to draw robust evidence and therefore the results of this review should not be used for counselling, intervention or therapeutic purposes. Due to the rarity of the condition, high-quality data from randomized-controlled trials or Comparative effectiveness research, with more homogenous definitions of outcomes and standardized management are required to better estimate clinically relevant perinatal outcomes and guide clinicians in counselling parents.

\section{References}

This article is protected by copyright. All rights reserved 
1. Khalil A, Rodgers M, Baschat A, et al. ISUOG Practice Guidelines: role of ultrasound in twin pregnancy. Ultrasound Obstet Gynecol. 2016;47:247-263.

2. Lewi L, Deprest J, Hecher K. The vascular anastomoses in monochorionic twin pregnancies and their clinical consequences. Am J Obstet Gynecol. 2013;208:19-30.

3. Mosquera C, Miller RS, Simpson LL. Twin-twin transfusion syndrome. Semin Perinatol. 2012;36:182-189.

4. Roberts D, Neilson JP, Kilby MD, Gates S. Interventions for the treatment of twin-twin transfusion syndrome. Cochrane Database Syst Rev 2014; 1: CD002073.

5. Senat MV, Deprest J, Boulvain M, Paupe A, Winer N, Ville Y. Endoscopic laser surgery versus serial amnioreduction for severe twin-to-twin transfusion syndrome. N Engl J Med. 2004;351:136144

6. Diehl W, Diemert A, Grasso D, Sehner S, Wegscheider K, Hecher K. Fetoscopic laser coagulation in 1020 pregnancies with twin-twin transfusion syndrome demonstrates improvement in double-twin survival rate. Ultrasound Obstet Gynecol. 2017;50:728-735.

7. Van Klink J, Koopman H, Rijken M, Middeldorp J, Oepkes D, Lopriore E. Long-term neurodevelopmental outcome in survivors of twin-to-twin transfusion syndrome. Twin Res Hum Genet. 2016;19:255-261.

8. Di Mascio D, Khalil A, Rizzo G, et al. Risk of fetal loss following amniocentesis or chorionic villus sampling in twin pregnancy: systematic review and meta-analysis. Ultrasound Obstet Gynecol. 2020;56:647-655.

9. Gratacos E, Deprest J. Current experience with fetoscopy and the Eurofoetus registry for fetoscopic procedures. Eur J Obstet Gynecol Reprod Biol 2000; 92: 151-159.

10. Dickinson JE, Evans SF. The progression of disease stage in twin-twin transfusion syndrome. J Matern Fetal Neonatal Med 2004;16: 95-101.

11. Mari G, Roberts A, Detti L, et al. Perinatal morbidity and mortality rates in severe twin-twin transfusion syndrome: results of the International Amnioreduction Registry. Am J Obstet Gynecol 2001;185:708-15.

12. Rossi AC, D'addario V. Laser therapy and serial amnioreduction as treatment for twin-twin transfusion syndrome: a metaanalysis and review of literature. Am J Obstet Gynecol. 2008;198:147-52.

This article is protected by copyright. All rights reserved 
13. Rizzolo A, Shah PS, Boucorian I, et al. Cumulative effect of evidence-based practices on outcomes of preterm infants born at $<29$ weeks' gestational age. Am J Obstet Gynecol. 2020;222:181.e1-181.e10.

14. Middeldorp JM, Lopriore E, Sueters M, et al. Twin-to-twin transfusion syndrome after 26 weeks of gestation: is there a role for fetoscopic laser surgery? BJOG. 2007;114:694-8.

15. Valsky DV, Eixarch E, Martinez-Crespo JM, et al. Fetoscopic laser surgery for twin-to-twin transfusion syndrome after 26 weeks of gestation. Fetal Diagn Ther. 2012;31:30-4.

16. Baud D, Windrim R, Keunen J, et al. Fetoscopic laser therapy for twin-twin transfusion syndrome before 17 and after 26 weeks' gestation. Am J Obstet Gynecol. 2013;208:197.e1-7.

17. Prisma statement. http://www.prisma-statement.org/ [accessed 10 June 2020].

18. Stroup DF, Berlin JA, Morton SC, et al. Meta-analysis of observational studies in epidemiology: a proposal for reporting. Meta-analysis Of Observational Studies in Epidemiology (MOOSE) group. JAMA. 2000;283:2008-12.

19. Wells GA, Shea B, O'Connell D, et al. The Newcastle-Ottawa Scale (NOS) for Assessing the Quality of Nonrandomised Studies in Meta-analyses.

http://www.ohri.ca/programs/clinical_epidemiology/oxford.asp. [Accessed June 10, 2020]

20. Murad MH, Sultan S, Haffar S, Bazerbachi F. Methodological quality and synthesis of case series and case reports. BMJ Evid Based Med.2018;23:60-63.

21. Guyatt GH, Oxman AD, Kunz R, et al. What is "quality of evidence" and why is it important to clinicians? BMJ. 2008;336:995-8.

22. Guyatt GH, Oxman AD, Vist GE, et al. GRADE Working Group. GRADE: an emerging consensus on rating quality of evidence and strength of recommendations. BMJ. 2008;336:924-6. 23. Higgins J, Thompson S, Deeks J, Altman D. Statistical heterogeneity in systematic reviews of clinical trials: a critical appraisal of guidelines and practice. J Health Serv Res Policy. 2002;7:5161.

24. Egger M, Davey Smith G, Schneider M, Minder C. Bias in meta-analysis detected by a simple, graphical test. BMJ. 1997;315:629-634.

25. Hunter JP, Saratzis A, Sutton AJ, Boucher RH, Sayers RD, Bown MJ. In meta-analyses of proportion studies, funnel plots were found to be an inaccurate method of assessing publication bias. J Clin Epidemiol. 2014;67:897-903. 
26. Nakata M, Ishii K, Sumie M, et al. A prospective pilot study of fetoscopic laser surgery for twin-to-twin transfusion syndrome between 26 and 27 weeks of gestation. Taiwan J Obstet Gynecol. 2016;55:512-514.

27. Murata M, Ishii K, Taguchi T, et al. The prevalence and clinical features of twin-twin transfusion syndrome with onset during the third trimester. J Perinat Med. 2014;42:93-98.

28. Merhar SL, Kline-Fath BM, Meinzen-Derr J, Schibler KR, Leach JL. Fetal and postnatal brain MRI in premature infants with twin-twin transfusion syndrome. J Perinatol. 2013;33:112-118.

29. Has R, Akhan S, Topuz S, Ermiş H, Iyibozkurt C, Ibrahimoğlu L. Therapeutic amniocentesis for treatment of twin-twin transfusion syndrome. Arch Gynecol Obstet. 2005;271:22-25.

30. Gul A, Aslan H, Polat I, et al. Natural history of 11 cases of twin-twin transfusion syndrome without intervention. Twin Res. 2003;6:263-266.

31. Blaicher W, Ulm B, Ulm M, Kuhle S, Deutinger J, Bernaschek G. The twin-twin transfusion syndrome - an unsolved problem. Ultraschall Med. 2002;23:108-112.

32. Quintero RA, Dickinson JE, Morales WJ, et al. Stage-based treatment of twin-twin transfusion syndrome. Am J Obstet Gynecol. 2003;188:1333-1340.

33. Khalil A, Liu B. Controversies in the management of twin pregnancies. Ultrasound Obstet Gynecol. 2020 Aug 16. doi: 10.1002/uog.22181. Epub ahead of print. PMID: 32799348.

34. Ville Y, Hecher K, Gagnon A, Sebire N, Hyett J, Nicolaides K. Endoscopic laser coagulation in the management of severe twin-to-twin transfusion syndrome. Br J Obstet Gynaecol. 1998;105:446-453.

35. Hecher K, Diehl W, Zikulnig L, Vetter M, Hackelöer BJ: Endoscopic laser coagulation of placental anastomoses in 200 pregnancies with severe mid-trimester twin-to-twin transfusion syndrome. Eur J Obstet Gynecol Reprod Biol 2000; 92: 135-139.

36. Rodeck CH, Weisz B, Peebles DM, Jauniaux E: Hypothesis: the placental 'steal' phenomenon - a possible hazard of amnioreduction. Fetal Diagn Ther 2006;21:302-306.

37. Fichera A, Ambrosi C, Taddei F, Gasparotti R, Frusca T. Severe brain damage from twin-twin transfusion syndrome treated with serial amnioreductions after 26 weeks: a case to reconsider the gestational age limits of laser therapy. Fetal Diagn Ther. 2009;25:203-205.

38. Perry H, Duffy JMN, Umadia O, Khalil A. International Collaboration to Harmonise Outcomes for Twin-Twin Transfusion Syndrome (CHOOSE). Outcome reporting across randomized trials and observational studies evaluating treatments for twin-twin transfusion syndrome: systematic review. Ultrasound Obstet Gynecol.2018;52:577-585.

This article is protected by copyright. All rights reserved 


\section{Legends}

Figure 1 - Flow chart illustrating identification of studies included in this systematic review.

Table 1. General characteristics and quality assessment of the included studies.

Table 2: Pooled proportions (PP) of the incidence of mortality and obstetric outcomes explored in the present review in monochorionic diamniotic (MCDA) twin pregnancies complicated by late twin-twin transfusion syndrome.

Table 3: Pooled proportions (PP) for the incidence of neonatal outcomes explored in the present review in monochorionic diamniotic (MCDA) twin pregnancies complicated by late twin-twin transfusion syndrome.

Table 4 - GRADE system evidence table summarizing the main outcomes measured according to management.

\section{Supporting information legends}

Table S1. Search Strategy.

Table S2. Tool for evaluating the methodological quality of case reports and case series.

Table S3. List of excluded references with reason for exclusion. 
Table 1. General characteristics and quality assessment of the included studies

\begin{tabular}{|c|c|c|c|c|c|c|c|c|c|}
\hline $\begin{array}{l}\text { First } \\
\text { Author } \\
\text { (publicati } \\
\text { on year) }\end{array}$ & $\begin{array}{l}\text { Country } \\
\text { (Design) }\end{array}$ & $\begin{array}{l}\text { Type of } \\
\text { study } \\
\text { (study } \\
\text { period) }\end{array}$ & $\begin{array}{l}\text { Gestational } \\
\text { Age at } \\
\text { diagnosis in } \\
\text { weeks* }\end{array}$ & $\begin{array}{c}\text { Gestational } \\
\text { Age at } \\
\text { delivery in } \\
\text { weeks* }\end{array}$ & $\begin{array}{c}\text { Cases } \\
\text { affected by } \\
\text { TTTS (n) }\end{array}$ & $\begin{array}{l}\text { Cases affected } \\
\text { by late }(\geq 26 \\
\text { weeks) TTTS } \\
\text { (n) }\end{array}$ & Management & Outcomes & Quality Assessment \\
\hline $\begin{array}{l}\text { Nakata }^{20} \\
\text { (2016) }\end{array}$ & $\begin{array}{c}\text { Japan } \\
\text { (Prospective) }\end{array}$ & $\begin{array}{l}\text { Cohort study } \\
(2012-2013)\end{array}$ & $\begin{array}{c}26.9(26.1- \\
27.6)^{\S}\end{array}$ & $\begin{array}{c}30.9(28- \\
36.6)\end{array}$ & 6 & 6 & FLA & $\begin{array}{l}\text { Neonatal mortality, } \\
\text { Perinatal outcomes, } \\
\text { Survival and Intact } \\
\text { survival }\end{array}$ & Low Quality^ \\
\hline $\begin{array}{l}\text { Murata }^{2 \prime} \\
\text { (2014) }\end{array}$ & $\begin{array}{c}\text { Japan } \\
\text { (Retrospecti } \\
\text { ve) }\end{array}$ & $\begin{array}{l}\text { Case series } \\
(2009-2012)\end{array}$ & $\begin{array}{c}33.7(31.3- \\
35.7)\end{array}$ & $\begin{array}{c}33.7(31.3- \\
35.7)\end{array}$ & 15 & 5 & Delivery & $\begin{array}{l}\text { Neonatal morbidity } \\
\text { and mortality, } \\
\text { Perinatal outcomes, } \\
\text { Survival and Intact } \\
\text { survival }\end{array}$ & Low Quality^^ \\
\hline $\begin{array}{l}\text { Merhar }^{28} \\
(2013)\end{array}$ & $\begin{array}{l}\text { USA } \\
\text { (NS) }\end{array}$ & $\begin{array}{l}\text { Case series } \\
(2009-2011)\end{array}$ & $\begin{array}{c}26.4(26.1- \\
26.6)\end{array}$ & $\begin{array}{c}27.5(26.4- \\
33)\end{array}$ & 11 & 3 & $\begin{array}{c}\text { FLA, } \\
\text { Amnioreduction }\end{array}$ & $\begin{array}{l}\text { Mortality, obstetric, } \\
\text { morbidity, } \\
\text { neuromorbidity, } \\
\text { RDS }\end{array}$ & Low Quality^ \\
\hline $\begin{array}{l}\text { Baud }^{16} \\
(2013)\end{array}$ & $\begin{array}{c}\text { USA } \\
\text { (Retrospecti } \\
\text { ve) }\end{array}$ & $\begin{array}{l}\text { Cohort study } \\
(1999-2012)\end{array}$ & $\begin{array}{c}26.6(26- \\
30.3)^{\S}\end{array}$ & $\begin{array}{c}33.9(26.6- \\
37.1)\end{array}$ & 325 & 18 & FLA & $\begin{array}{l}\text { Neonatal morbidity } \\
\text { and mortality, } \\
\text { Perinatal outcomes, }\end{array}$ & 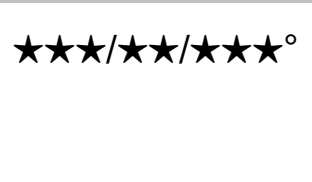 \\
\hline
\end{tabular}

This article is protected by copyright. All rights reserved 


\begin{tabular}{|c|c|c|c|c|c|c|c|c|c|}
\hline & & & & & & & & Survival & \\
\hline $\begin{array}{l}\text { Valsky }^{15} \\
(2011)\end{array}$ & $\begin{array}{l}\text { Belgium and } \\
\text { Spain } \\
\text { (Prospective) }\end{array}$ & $\begin{array}{l}\text { Cohort study } \\
(2006-2009)\end{array}$ & $\begin{array}{c}26.3(26- \\
29.3)^{\S}\end{array}$ & $\begin{array}{c}33.0(26.0- \\
38.4)\end{array}$ & 352 & 28 & FLA & $\begin{array}{c}\text { Neonatal mortality, } \\
\text { Perinatal outcomes, } \\
\text { Survival }\end{array}$ & 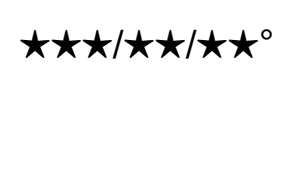 \\
\hline $\begin{array}{l}\text { Middledor } \\
p^{14}(2007)\end{array}$ & $\begin{array}{c}\text { Netherlands } \\
\text { (Retrospecti } \\
\text { ve) }\end{array}$ & $\begin{array}{c}\text { Cohort study } \\
\text { (1991-2006) }\end{array}$ & $\begin{array}{c}\text { A: } 27(26- \\
29)^{\S} \\
\text { FLA: } 27(26- \\
28)^{\S}\end{array}$ & $\begin{array}{c}\text { A: } 29(27-36) \\
\text { FLA: } 31 \text { (28- } \\
37)\end{array}$ & 21 & 21 & $\begin{array}{c}\text { FLA, } \\
\text { Amnioreduction }\end{array}$ & $\begin{array}{l}\text { Neonatal mortality, } \\
\text { Perinatal outcomes }\end{array}$ & 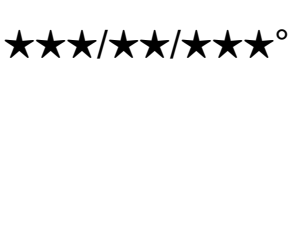 \\
\hline $\begin{array}{l}\operatorname{Has}^{2 y} \\
(2005)\end{array}$ & $\begin{array}{c}\text { Turkey } \\
\text { (Retrospecti } \\
\text { ve) }\end{array}$ & $\begin{array}{l}\text { Case series } \\
(1999-2002)\end{array}$ & $\begin{array}{c}\text { A: } 27.8 \\
(26.7-28.9) \\
\text { E: } 26.1(26- \\
26.9)\end{array}$ & $\begin{array}{c}\text { A: } 33.3(31.6- \\
35) \\
\text { E: } 31(30.1- \\
33)\end{array}$ & 17 & 5 & $\begin{array}{l}\text { Amnioreduction, } \\
\text { Expectant }\end{array}$ & $\begin{array}{c}\text { Neonatal mortality, } \\
\text { Perinatal outcomes, } \\
\text { Neurological } \\
\text { postnatal outcomes, } \\
\text { Intact survival }\end{array}$ & Low Quality^ \\
\hline $\begin{array}{l}\mathrm{Gul}^{30} \\
(2003)\end{array}$ & $\begin{array}{c}\text { Turkey } \\
\text { (Retrospecti } \\
\text { ve) }\end{array}$ & $\begin{array}{l}\text { Case series } \\
(1998-2001)\end{array}$ & $31.5(27-34)$ & $\begin{array}{c}31.6(30.1- \\
35)\end{array}$ & 21 & 5 & $\begin{array}{l}\text { Amnioreduction, } \\
\text { Expectant }\end{array}$ & $\begin{array}{c}\text { Neonatal mortality, } \\
\text { Perinatal outcomes, } \\
\text { Neurological } \\
\text { postnatal outcomes }\end{array}$ & Low Quality^^ \\
\hline $\begin{array}{l}\text { Blaicher }^{31} \\
(2002)\end{array}$ & $\begin{array}{c}\text { Austria } \\
\text { (Retrospecti } \\
\text { ve) }\end{array}$ & $\begin{array}{l}\text { Case series } \\
(1998-2000)\end{array}$ & $27(26-31)$ & $29(27-32)$ & 28 & 3 & Amnioreduction & $\begin{array}{l}\text { Neonatal morbidity } \\
\text { and mortality, } \\
\text { Perinatal outcomes, } \\
\text { Neurological }\end{array}$ & Low Quality^ \\
\hline
\end{tabular}

This article is protected by copyright. All rights reserved 


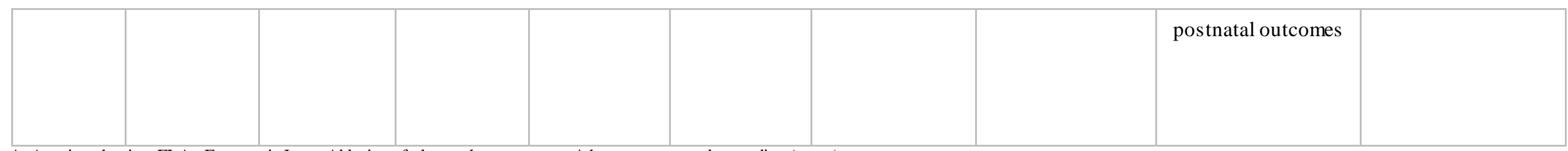

A: Amnioreduction; FLA= Fetoscopic Laser Ablation of placental anastomoses; *data are expressed as median (range)

${ }^{\S}$ Gestational Age at intervention used as a proxy for GA at diagnosis

${ }^{\circ}$ Cohort/Case-control studies assessed according to Newcastle-Ottawa Scale (NOS) (assessment based on selection/comparability/exposure-outcome. Highest scores are 4 for selection, 2 for comparability and 3 for exposure-outcome) (14)

${ }^{\wedge}$ Case series/reports assessed with a tool that published at BMJ Evidence-Based-Medicine Journal on April 2018 (Supplementary T able 2). Authors specifically mention about not to use an aggregate score for this tool on the other hand making overall judgment like we do (low or high quality) is much more appropriate (15)

This article is protected by copyright. All rights reserved 
Table 2: Pooled proportions (PP) of the incidence of mortality and obstetric outcomes explored in the present review in monochorionic diamniotic (MCDA) twin pregnancies complicated by late twin-twin transfusion syndrome

\begin{tabular}{|c|c|c|c|c|c|c|c|c|c|c|c|c|c|c|c|c|}
\hline Outcome & $\begin{array}{l}\text { Stud } \\
\text { ies } \\
(n)\end{array}$ & $\begin{array}{c}\text { Fetus } \\
\text { es } \\
(\mathbf{n} / \mathbf{N})\end{array}$ & $\begin{array}{c}\text { Pooled } \\
\text { proportio } \\
\text { ns (95\% } \\
\text { CI) }\end{array}$ & $\begin{array}{c}\mathbf{I}^{2} \\
(\%)\end{array}$ & $\begin{array}{l}\text { Stud } \\
\text { ies } \\
(n)\end{array}$ & $\begin{array}{c}\text { Fetus } \\
\text { es } \\
(\mathbf{n} / \mathbf{N})\end{array}$ & $\begin{array}{c}\text { Pooled } \\
\text { proportio } \\
\text { ns (95\% } \\
\text { CI) }\end{array}$ & $\begin{array}{l}\mathbf{I}^{2} \\
(\%)\end{array}$ & $\begin{array}{l}\text { Stud } \\
\text { ies } \\
\text { (n) }\end{array}$ & $\begin{array}{l}\text { Fetus } \\
\text { es } \\
(\mathrm{n} / \mathrm{N})\end{array}$ & $\begin{array}{l}\text { Pooled } \\
\text { propor } \\
\text { tions } \\
(95 \% \\
\text { CI })\end{array}$ & $\begin{array}{l}\mathbf{I}^{2} \\
(\% \\
)\end{array}$ & $\begin{array}{l}\text { Stud } \\
\text { ies } \\
\text { (n) }\end{array}$ & $\begin{array}{l}\text { Fetus } \\
\text { es } \\
(\mathbf{n} / \mathbf{N})\end{array}$ & $\begin{array}{l}\text { Pooled } \\
\text { proporti } \\
\text { ons } \\
(95 \% \\
\text { CI) }\end{array}$ & $\begin{array}{l}\mathbf{I}^{2} \\
(\%)\end{array}$ \\
\hline & \multicolumn{4}{|c|}{ Expectant management } & \multicolumn{4}{|c|}{ Fetoscopic laser ablation } & \multicolumn{4}{|c|}{ Amnioreduction } & \multicolumn{4}{|c|}{ Delivery } \\
\hline IUD (overall) & 3 & $3 / 20$ & $\begin{array}{c}17.69 \\
(4.9-36.2)\end{array}$ & 0 & 4 & $4 / 72$ & $\begin{array}{c}5.27(0.9- \\
12.9)\end{array}$ & 21.7 & 5 & $0 / 40$ & $\begin{array}{l}0(0- \\
9.0)\end{array}$ & 0 & 1 & $0 / 10$ & $\begin{array}{l}0(0- \\
30.8)\end{array}$ & - \\
\hline Single IUD & 3 & $3 / 20$ & $\begin{array}{c}17.69 \\
(4.9-36.2)\end{array}$ & 0 & 4 & $4 / 72$ & $\begin{array}{c}5.27(0.9- \\
12.9)\end{array}$ & 21.7 & 5 & $0 / 40$ & $\begin{array}{l}0(0- \\
9.0)\end{array}$ & 0 & 1 & $0 / 10$ & $\begin{array}{l}0(0- \\
30.8)\end{array}$ & - \\
\hline Double IUD & 3 & $0 / 20$ & $0(0-14.7)$ & 0 & 4 & $0 / 72$ & $0(0-4.9)$ & 0 & 5 & $0 / 40$ & $\begin{array}{l}0(0- \\
9.0)\end{array}$ & 0 & 1 & $0 / 10$ & $\begin{array}{l}0(0- \\
30.8)\end{array}$ & - \\
\hline $\begin{array}{l}\text { IUD (donor } \\
\text { twin) }\end{array}$ & 2 & $1 / 5$ & $\begin{array}{c}23.83 \\
(1.2-62.3)\end{array}$ & 0 & 4 & $3 / 36$ & $\begin{array}{c}9.38(2.3- \\
20.5)\end{array}$ & 0 & 5 & $0 / 40$ & $\begin{array}{l}0(0- \\
9.0)\end{array}$ & 0 & 1 & $0 / 10$ & $\begin{array}{l}0(0- \\
30.8)\end{array}$ & - \\
\hline $\begin{array}{l}\text { IUD } \\
\text { (recipient } \\
\text { twin) }\end{array}$ & 2 & $0 / 5$ & $0(0-39.6)$ & 0 & 4 & $1 / 36$ & $\begin{array}{c}5.31(0.5- \\
14.6)\end{array}$ & 0 & 5 & $0 / 40$ & $\begin{array}{l}0(0- \\
9.0)\end{array}$ & 0 & 1 & $0 / 10$ & $\begin{array}{l}0(0- \\
30.8)\end{array}$ & - \\
\hline & & & & & & & & & & & & & & & & \\
\hline
\end{tabular}

This article is protected by copyright. All rights reserved 


\begin{tabular}{|c|c|c|c|c|c|c|c|c|c|c|c|c|c|c|c|c|}
\hline NND (overall) & 3 & $8 / 20$ & $\begin{array}{c}42.49 \\
(17.5- \\
69.7)\end{array}$ & 39.1 & 4 & $1 / 72$ & $\begin{array}{c}2.76(0.3- \\
7.7)\end{array}$ & 0 & 4 & $3 / 18$ & $\begin{array}{l}20.19 \\
(6.0- \\
40.0)\end{array}$ & 0 & 1 & $0 / 10$ & $\begin{array}{l}0(0- \\
30.8)\end{array}$ & - \\
\hline Single NND & 3 & $4 / 20$ & $\begin{array}{c}22.89 \\
(1.0-61.1)\end{array}$ & 69.8 & 4 & $1 / 72$ & $\begin{array}{c}2.76(0.3- \\
7.7)\end{array}$ & 0 & 4 & $1 / 18$ & $\begin{array}{l}7.99 \\
(0.5- \\
23.6)\end{array}$ & 0 & 1 & $0 / 10$ & $\begin{array}{l}0(0- \\
30.8)\end{array}$ & - \\
\hline Double NND & 3 & $2 / 20$ & $\begin{array}{c}13.40 \\
(2.6-30.6)\end{array}$ & 0 & 4 & $0 / 72$ & $0(0-4.9)$ & 0 & 4 & $1 / 18$ & $\begin{array}{l}10.24 \\
(1.1 .- \\
26.8)\end{array}$ & 0 & 1 & $0 / 10$ & $\begin{array}{l}0(0- \\
30.8)\end{array}$ & - \\
\hline $\begin{array}{l}\text { NND (donor } \\
\text { twin) }\end{array}$ & 2 & $3 / 8$ & $\begin{array}{c}38.84 \\
(11.5- \\
70.7)\end{array}$ & 26.3 & 4 & $0 / 36$ & $0(0-9.4)$ & 0 & 4 & $1 / 9$ & $\begin{array}{l}17.84 \\
(2.0- \\
44.6)\end{array}$ & 0 & 1 & $0 / 10$ & $\begin{array}{l}0(0- \\
30.8)\end{array}$ & - \\
\hline $\begin{array}{l}\text { NND } \\
\text { (recipient } \\
\text { twin) }\end{array}$ & 2 & $3 / 8$ & $\begin{array}{c}38.84 \\
(11.5- \\
70.7)\end{array}$ & 26.3 & 4 & $1 / 36$ & $\begin{array}{c}5.31(0.5- \\
14.6)\end{array}$ & 0 & 4 & 2.9 & $\begin{array}{c}26.84 \\
(6.1- \\
55.5)\end{array}$ & 0 & 1 & $0 / 10$ & $\begin{array}{l}0(0- \\
30.8)\end{array}$ & - \\
\hline PND (overall) & 3 & $11 / 20$ & $\begin{array}{l}55.69 \\
(31.4- \\
78.6)\end{array}$ & 24.3 & 4 & $5 / 72$ & $\begin{array}{c}5.55(0.5- \\
15.3)\end{array}$ & 42.8 & 4 & $3 / 18$ & $\begin{array}{l}20.19 \\
(6.0- \\
40.0)\end{array}$ & 0 & 1 & $0 / 10$ & $\begin{array}{l}0(0- \\
30.8)\end{array}$ & - \\
\hline Single PND & 3 & $5 / 20$ & $\begin{array}{l}27.32 \\
(11.0-\end{array}$ & 0 & 4 & $3 / 72$ & $\begin{array}{c}4.85(1.2- \\
10.9)\end{array}$ & 0 & 4 & $1 / 18$ & $\begin{array}{l}7.99 \\
(0.5-\end{array}$ & 0 & 1 & $0 / 10$ & $\begin{array}{l}0(0- \\
30.8)\end{array}$ & - \\
\hline
\end{tabular}

This article is protected by copyright. All rights reserved 


\begin{tabular}{|c|c|c|c|c|c|c|c|c|c|c|c|c|c|c|c|c|}
\hline & & & $47.6)$ & & & & & & & & 23.6) & & & & & \\
\hline Double PND & 3 & $6 / 20$ & $\begin{array}{c}16.93 \\
(4.5-35.2)\end{array}$ & 0 & 4 & $1 / 72$ & $\begin{array}{c}2.76(0.3- \\
7.7)\end{array}$ & 0 & 4 & $1 / 18$ & $\begin{array}{l}10.24 \\
(1.1 .- \\
26.8)\end{array}$ & 0 & 1 & $0 / 10$ & $\begin{array}{l}0(0- \\
30.8)\end{array}$ & - \\
\hline $\begin{array}{l}\text { PND (donor } \\
\text { twin) }\end{array}$ & 1 & $3 / 3$ & $\begin{array}{c}100(29.2- \\
100)\end{array}$ & - & 4 & $3 / 36$ & $\begin{array}{c}9.38(2.3- \\
20.5)\end{array}$ & 0 & 4 & $1 / 9$ & $\begin{array}{l}17.84 \\
(2.0- \\
84.6)\end{array}$ & 0 & 1 & $0 / 10$ & $\begin{array}{l}0(0- \\
30.8)\end{array}$ & - \\
\hline $\begin{array}{l}\text { PND } \\
\text { (recipient } \\
\text { twin) }\end{array}$ & 1 & $2 / 3$ & $\begin{array}{c}66.67 \\
(9.4-99.2)\end{array}$ & - & 4 & $2 / 36$ & $\begin{array}{c}\text { 7.41 (1.4- } \\
17.7)\end{array}$ & 0 & 4 & $2 / 9$ & $\begin{array}{l}26.84 \\
(6.1- \\
85.5)\end{array}$ & 0 & 1 & $0 / 10$ & $\begin{array}{l}0(0- \\
30.8)\end{array}$ & - \\
\hline $\begin{array}{l}\text { Double } \\
\text { survival (per } \\
\text { pregnancy) }\end{array}$ & 3 & $2 / 10$ & $\begin{array}{c}21.36 \\
(3.5-48.8)\end{array}$ & 1.6 & 5 & $51 / 62$ & $\begin{array}{l}85.42 \\
(71.2- \\
95.4)\end{array}$ & 42.2 & 5 & $7 / 9$ & $\begin{array}{l}73.13 \\
(44.5- \\
93.9)\end{array}$ & 0 & 1 & $5 / 5$ & $\begin{array}{c}100 \\
(47.8- \\
100)\end{array}$ & - \\
\hline $\begin{array}{l}\text { At least one } \\
\text { survivor (per } \\
\text { pregnancy) }\end{array}$ & 3 & $7 / 10$ & $\begin{array}{l}68.72 \\
(37.3- \\
92.7)\end{array}$ & 16.7 & 5 & $59 / 62$ & $\begin{array}{l}93.22 \\
(85.9- \\
98.0)\end{array}$ & 0 & 5 & $8 / 9$ & $\begin{array}{l}82.16 \\
(55.4- \\
98.0)\end{array}$ & 0 & 1 & $5 / 5$ & $\begin{array}{c}100 \\
(47.8- \\
100)\end{array}$ & - \\
\hline $\begin{array}{l}\text { No survivor } \\
\text { (per } \\
\text { pregnancy) }\end{array}$ & 3 & $3 / 10$ & $\begin{array}{c}31.28 \\
(7.3-62.7)\end{array}$ & 16.7 & 5 & $3 / 62$ & $\begin{array}{c}6.78(2.0- \\
14.1)\end{array}$ & 0 & 5 & $1 / 9$ & $\begin{array}{l}17.84 \\
(2.0- \\
44.6)\end{array}$ & 0 & 1 & $0 / 5$ & $\begin{array}{l}0(0- \\
52.2)\end{array}$ & - \\
\hline
\end{tabular}

This article is protected by copyright. All rights reserved 


\begin{tabular}{|c|c|c|c|c|c|c|c|c|c|c|c|c|c|c|c|c|}
\hline $\begin{array}{l}\text { PTB }(<32 \\
\text { weeks })\end{array}$ & 3 & $4 / 10$ & $\begin{array}{c}41.24 \\
(15.8- \\
69.6)\end{array}$ & 0 & 4 & $17 / 54$ & $\begin{array}{c}32.33 \\
(20.8- \\
45.0)\end{array}$ & 0 & 4 & $5 / 9$ & $\begin{array}{c}56.44 \\
(27.7- \\
83.0)\end{array}$ & 0 & 1 & $2 / 5$ & $\begin{array}{l}40.0 \\
(5.3- \\
85.3)\end{array}$ & - \\
\hline & & & & & & & & & & & & & & & & \\
\hline
\end{tabular}

IUD, intrauterine death; NND, neonataldeath; PND, perinatal death; PTB, preterm birth 
Table 3: Pooled proportions (PP) for the incidence of neonatal outcomes explored in the present review in monochorionic diamniotic (MCDA) twin pregnancies complicated by late twin-twin transfusion syndrome

\begin{tabular}{|c|c|c|c|c|c|c|c|c|c|c|c|c|c|c|c|}
\hline Outcome & $\begin{array}{c}\text { Studies } \\
\text { (n) }\end{array}$ & $\begin{array}{c}\text { Fetuses } \\
(\mathbf{n} / \mathbf{N})\end{array}$ & $\begin{array}{c}\text { Pooled } \\
\text { proportions } \\
(95 \% \mathrm{CI})\end{array}$ & $\begin{array}{c}\mathbf{I}^{2} \\
(\%)\end{array}$ & $\begin{array}{l}\text { Studies } \\
\text { (n) }\end{array}$ & $\begin{array}{c}\text { Fetuses } \\
(\mathbf{n} / \mathbf{N})\end{array}$ & $\begin{array}{c}\text { Pooled } \\
\text { proportions } \\
(95 \% \mathrm{CI})\end{array}$ & $\begin{array}{c}\mathrm{I}^{2} \\
(\%)\end{array}$ & $\begin{array}{c}\text { Studies } \\
\text { (n) }\end{array}$ & $\begin{array}{c}\text { Fetuses } \\
(\mathbf{n} / \mathbf{N})\end{array}$ & $\begin{array}{c}\text { Pooled } \\
\text { proportions } \\
(95 \% \mathrm{CI})\end{array}$ & $\begin{array}{c}I^{2} \\
(\%)\end{array}$ & $\begin{array}{c}\text { Studies } \\
\text { (n) }\end{array}$ & $\begin{array}{c}\text { Fetuses } \\
(\mathbf{n} / \mathbf{N})\end{array}$ & $\begin{array}{c}\text { Pooled } \\
\text { proportions } \\
(95 \% \mathrm{CI})\end{array}$ \\
\hline & \multicolumn{4}{|c|}{ Expectant Management } & \multicolumn{4}{|c|}{ Fetoscopic laser ablation } & \multicolumn{4}{|c|}{ Amnioreduction } & \multicolumn{3}{|c|}{ Delivery } \\
\hline $\begin{array}{c}\text { Composite } \\
\text { morbidity } \\
\text { (overall) }\end{array}$ & 2 & $1 / 9$ & $\begin{array}{c}13.64(0.1- \\
44.9)\end{array}$ & 23.7 & 3 & $8 / 56$ & $\begin{array}{c}31.89(18.3- \\
76.5)\end{array}$ & 90.2 & 4 & $8 / 30$ & $\begin{array}{c}25.88(11.0- \\
44.4)\end{array}$ & 7.9 & 1 & $7 / 10$ & $\begin{array}{c}70.0(34.8- \\
93.3)\end{array}$ \\
\hline $\begin{array}{c}\text { Composite } \\
\text { morbidity } \\
\text { (donor) }\end{array}$ & 1 & $0 / 2$ & $0(0-84.2)$ & - & 2 & $2 / 17$ & $\begin{array}{c}37.38(19.2- \\
96.1)\end{array}$ & 91 & 2 & $1 / 3$ & $\begin{array}{c}35.10(20.6- \\
81.3)\end{array}$ & 64.8 & 1 & $2 / 5$ & $\begin{array}{c}40.0(5.3- \\
85.3)\end{array}$ \\
\hline $\begin{array}{c}\text { Composite } \\
\text { morbidity } \\
\text { (recipient) }\end{array}$ & 1 & $0 / 3$ & $0(0-70.8)$ & - & 2 & $3 / 19$ & $\begin{array}{c}44.67(4.7- \\
98.8)\end{array}$ & 88 & 2 & $1 / 3$ & $\begin{array}{c}35.10(20.6- \\
81.3)\end{array}$ & 64.8 & 1 & $5 / 5$ & $\begin{array}{c}100(47.8- \\
100)\end{array}$ \\
\hline $\begin{array}{c}\text { Neuromorbidity } \\
\text { (overall) }\end{array}$ & 2 & $1 / 9$ & $\begin{array}{c}13.64(0.1- \\
44.9)\end{array}$ & 23.7 & 3 & $7 / 56$ & $\begin{array}{c}20.98(2.0- \\
52.5)\end{array}$ & 80.8 & 4 & $7 / 30$ & $\begin{array}{c}26.70(36.1- \\
60.9)\end{array}$ & 59.8 & 0 & - & - \\
\hline $\begin{array}{c}\text { Neuromorbidity } \\
\text { (donor) }\end{array}$ & 1 & $0 / 2$ & $0(0-84.2)$ & - & 2 & $2 / 17$ & $\begin{array}{c}37.38(19.2- \\
96.1)\end{array}$ & 91 & 3 & $1 / 4$ & $\begin{array}{c}28.96(2.2- \\
69.5)\end{array}$ & 35.4 & 0 & - & - \\
\hline
\end{tabular}




\begin{tabular}{|c|c|c|c|c|c|c|c|c|c|c|c|c|c|c|c|}
\hline $\begin{array}{l}\text { Neuromorbidity } \\
\text { (recipient) }\end{array}$ & 1 & $0 / 3$ & $0(0-70.8)$ & - & 2 & $2 / 19$ & $\begin{array}{c}18.98 \\
(0.003-62.0)\end{array}$ & 53.6 & 3 & $1 / 4$ & $\begin{array}{c}28.96(2.2- \\
69.5)\end{array}$ & 35.4 & 0 & - & - \\
\hline $\begin{array}{c}\text { Severe } \\
\text { neuromorbidity } \\
\text { (overall) }\end{array}$ & 1 & $0 / 4$ & $0(0-60.2)$ & - & 2 & $1 / 52$ & $\begin{array}{c}2.95(0.1- \\
9.1)\end{array}$ & 0 & 2 & $1 / 52$ & $\begin{array}{c}2.95(0.1- \\
9.1)\end{array}$ & 0 & 0 & - & - \\
\hline $\begin{array}{c}\text { Severe } \\
\text { neuromorbidity } \\
\text { (donor) }\end{array}$ & 0 & - & - & - & 1 & $0 / 15$ & $0(0-21.8)$ & - & 1 & $0 / 15$ & $0(0-21.8)$ & - & 0 & - & - \\
\hline $\begin{array}{c}\text { Severe } \\
\text { neuromorbidity } \\
\text { (recipient) }\end{array}$ & 0 & - & - & - & 1 & $1 / 17$ & $\begin{array}{c}5.88(0.1- \\
28.7)\end{array}$ & - & 1 & $1 / 17$ & $\begin{array}{c}5.88(0.1- \\
28.7)\end{array}$ & - & 0 & - & - \\
\hline RDS (ove rall) & 0 & - & - & - & 2 & $7 / 16$ & $\begin{array}{c}47.89(16.3- \\
80.4)\end{array}$ & 44.2 & 2 & $7 / 16$ & $\begin{array}{c}47.89(16.3- \\
80.4)\end{array}$ & 44.2 & 1 & $7 / 10$ & $\begin{array}{c}70.0(34.8- \\
93.3)\end{array}$ \\
\hline RDS (donor) & 0 & - & - & - & 2 & $4 / 8$ & $\begin{array}{c}61.52(8.6- \\
99.6)\end{array}$ & 64.5 & 2 & $4 / 8$ & $\begin{array}{c}61.52(8.6- \\
99.6)\end{array}$ & 64.5 & 1 & $2 / 5$ & $\begin{array}{c}40.0(5.3- \\
85.3)\end{array}$ \\
\hline RDS (recipient) & 0 & - & - & - & 2 & $3 / 8$ & $\begin{array}{c}39.49(11.9- \\
71.4)\end{array}$ & 0 & 2 & $3 / 8$ & $\begin{array}{c}39.49(11.9- \\
71.4)\end{array}$ & 0 & 1 & $5 / 5$ & $\begin{array}{c}100(47.8- \\
100)\end{array}$ \\
\hline $\begin{array}{c}\text { Admission to } \\
\text { NICU (overall) }\end{array}$ & 1 & $1 / 4$ & $\begin{array}{c}25.0(0.6- \\
80.6)\end{array}$ & - & 0 & - & - & - & 0 & - & - & - & 0 & - & - \\
\hline Admission to & 0 & - & - & - & 0 & - & - & - & 0 & - & - & - & 0 & - & - \\
\hline
\end{tabular}

This article is protected by copyright. All rights reserved 


\begin{tabular}{|c|c|c|c|c|c|c|c|c|c|c|c|c|c|c|c|}
\hline NICU (donor) & & & & & & & & & & & & & & & \\
\hline $\begin{array}{c}\text { Admission to } \\
\text { NICU } \\
\text { (recipient) }\end{array}$ & 0 & - & - & - & 0 & - & - & - & 0 & - & - & - & 0 & - & - \\
\hline $\begin{array}{c}\text { Intact survival } \\
\text { (overall) }\end{array}$ & 3 & $8 / 17$ & $\begin{array}{c}44.37(14.7- \\
76.5)\end{array}$ & 52 & 2 & $43 / 44$ & $\begin{array}{c}96.36(89.0- \\
99.8)\end{array}$ & 0 & 2 & $43 / 44$ & $\begin{array}{c}96.36(89.0- \\
99.8)\end{array}$ & 0 & 1 & $10 / 10$ & $\begin{array}{c}100(69.2- \\
100)\end{array}$ \\
\hline $\begin{array}{c}\text { Intact survival } \\
\text { (donor) }\end{array}$ & 1 & $0 / 3$ & $0(0-70.8)$ & - & 2 & $21 / 21$ & $\begin{array}{c}100(87.9- \\
100)\end{array}$ & 0 & 2 & $21 / 21$ & $\begin{array}{c}100(87.9- \\
100)\end{array}$ & 0 & 1 & $5 / 5$ & $\begin{array}{c}100(47.8- \\
100)\end{array}$ \\
\hline $\begin{array}{c}\text { Intact survival } \\
\text { (recipient) }\end{array}$ & 1 & $1 / 3$ & $\begin{array}{c}33.33(0.8- \\
90.6)\end{array}$ & - & 2 & $22 / 23$ & $\begin{array}{c}93.23(80.0- \\
99.6)\end{array}$ & 0 & 2 & $22 / 23$ & $\begin{array}{c}93.23(80.0- \\
99.6)\end{array}$ & 0 & 1 & $5 / 5$ & $\begin{array}{c}100(47.8- \\
100)\end{array}$ \\
\hline
\end{tabular}


Table 4 - GRADE system evidence table summarizing the main outcomes measured according to management.

\begin{tabular}{|c|c|c|c|c|c|c|c|c|c|}
\hline & & \multicolumn{5}{|c|}{ Quality assessment } & \multicolumn{3}{|c|}{ Summary of findings } \\
\hline Management & $\begin{array}{l}\text { N. of fetuses/ } \\
\text { pregnancies } \\
\text { (N. of studies) }\end{array}$ & $\begin{array}{c}\text { Study } \\
\text { limitations }\end{array}$ & Consistency & Directness & Precision & $\begin{array}{c}\text { Publication } \\
\text { bias }\end{array}$ & $\begin{array}{c}\text { Pooled } \\
\text { proportions } \\
(95 \% \mathrm{CI})\end{array}$ & $I^{2}(\%)$ & Quality \\
\hline \multicolumn{10}{|c|}{ Intrauterine Death (overall) } \\
\hline Expectant & $20(3)$ & $\begin{array}{c}\text { Serious } \\
\text { limitations }\end{array}$ & $\begin{array}{l}\text { Unexplained } \\
\text { heterogeneity }\end{array}$ & Direct & Imprecision & Likely & $17.69(4.9-36.2)$ & 0 & Very low \\
\hline Laser & $72(4)$ & $\begin{array}{c}\text { Serious } \\
\text { limitations }\end{array}$ & $\begin{array}{l}\text { No important } \\
\text { inconsistency }\end{array}$ & Direct & Imprecision & Likely & $5.27(0.9-12.9)$ & 21.7 & Very low \\
\hline Amnioreduction & $40(5)$ & $\begin{array}{c}\text { Serious } \\
\text { limitations }\end{array}$ & $\begin{array}{l}\text { Unexplained } \\
\text { heterogeneity }\end{array}$ & Direct & Imprecision & Likely & $0(0-9.0)$ & 0 & Very low \\
\hline \multicolumn{10}{|c|}{ Neonatal Death (overall) } \\
\hline Expectant & $20(3)$ & $\begin{array}{c}\text { Serious } \\
\text { limitations }\end{array}$ & $\begin{array}{l}\text { Unexplained } \\
\text { heterogeneity }\end{array}$ & Direct & Imprecision & Likely & $\begin{array}{c}42.49(17.5- \\
69.7)\end{array}$ & 39.1 & Very low \\
\hline Laser & $72(4)$ & $\begin{array}{c}\text { Serious } \\
\text { limitations }\end{array}$ & $\begin{array}{l}\text { No important } \\
\text { inconsistency }\end{array}$ & Direct & Imprecision & Likely & $2.76(0.3-7.7)$ & 0 & Very low \\
\hline Amnioreduction & $18(4)$ & $\begin{array}{c}\text { Serious } \\
\text { limitations }\end{array}$ & $\begin{array}{l}\text { Unexplained } \\
\text { heterogeneity }\end{array}$ & Direct & Imprecision & Likely & $20.19(6.0-40.0)$ & 0 & Very low \\
\hline
\end{tabular}

This article is protected by copyright. All rights reserved 


\begin{tabular}{|c|c|c|c|c|c|c|c|c|c|}
\hline Expectant & $20(3)$ & $\begin{array}{c}\text { Serious } \\
\text { limitations }\end{array}$ & $\begin{array}{l}\text { Unexplained } \\
\text { heterogeneity }\end{array}$ & Direct & Imprecision & Likely & $\begin{array}{c}55.69(31.4- \\
78.6)\end{array}$ & 24.3 & Very low \\
\hline Laser & $72(4)$ & $\begin{array}{c}\text { Serious } \\
\text { limitations }\end{array}$ & $\begin{array}{l}\text { Unexplained } \\
\text { heterogeneity }\end{array}$ & Direct & Imprecision & Unlikely & $5.55(0.5-15.3)$ & 42.8 & Very low \\
\hline Amnioreduction & $18(4)$ & $\begin{array}{c}\text { Serious } \\
\text { limitations }\end{array}$ & $\begin{array}{l}\text { Unexplained } \\
\text { heterogeneity }\end{array}$ & Direct & Imprecision & Likely & $20.19(6.0-40.0)$ & 0 & Very low \\
\hline \multicolumn{10}{|c|}{ No survivor (per pregnancy) } \\
\hline Expectant & $10(3)$ & $\begin{array}{c}\text { Serious } \\
\text { limitations }\end{array}$ & $\begin{array}{l}\text { Unexplained } \\
\text { heterogeneity }\end{array}$ & Direct & Imprecision & Likely & $31.28(7.3-62.7)$ & 16.7 & Very low \\
\hline Laser & $62(4)$ & $\begin{array}{c}\text { Serious } \\
\text { limitations }\end{array}$ & $\begin{array}{l}\text { No important } \\
\text { inconsistency }\end{array}$ & Direct & Imprecision & Likely & $6.78(2.0-14.1)$ & 0 & Very low \\
\hline Amnioreduction & $9(5)$ & $\begin{array}{c}\text { Serious } \\
\text { limitations }\end{array}$ & $\begin{array}{l}\text { Unexplained } \\
\text { heterogeneity }\end{array}$ & Direct & Imprecision & Likely & $17.84(2.0-44.6)$ & 0 & Very low \\
\hline \multicolumn{10}{|c|}{ Preterm birth $(<32$ weeks $)$} \\
\hline Expectant & $10(3)$ & $\begin{array}{c}\text { Serious } \\
\text { limitations }\end{array}$ & $\begin{array}{l}\text { Unexplained } \\
\text { heterogeneity }\end{array}$ & Direct & Imprecision & Likely & $\begin{array}{c}41.24(15.8- \\
69.6)\end{array}$ & 0 & Very low \\
\hline Laser & $54(4)$ & $\begin{array}{c}\text { Serious } \\
\text { limitations }\end{array}$ & $\begin{array}{l}\text { Unexplained } \\
\text { heterogeneity }\end{array}$ & Direct & Imprecision & Likely & $\begin{array}{c}32.33(20.8- \\
45.0)\end{array}$ & 0 & Very low \\
\hline Amnioreduction & $9(5)$ & $\begin{array}{c}\text { Serious } \\
\text { limitations }\end{array}$ & $\begin{array}{l}\text { Unexplained } \\
\text { heterogeneity }\end{array}$ & Direct & Imprecision & Likely & $\begin{array}{c}56.44(27.7- \\
83.0)\end{array}$ & 0 & Very low \\
\hline
\end{tabular}

This article is protected by copyright. All rights reserved 


\begin{tabular}{|c|c|c|c|c|c|c|c|c|c|}
\hline Expectant & $9(2)$ & $\begin{array}{c}\text { Serious } \\
\text { limitations }\end{array}$ & $\begin{array}{l}\text { Unexplained } \\
\text { heterogeneity }\end{array}$ & Direct & Imprecision & Likely & $13.64(0.1-44.9)$ & 23.7 & Very low \\
\hline Laser & $56(3)$ & $\begin{array}{c}\text { Serious } \\
\text { limitations }\end{array}$ & $\begin{array}{l}\text { Unexplained } \\
\text { heterogeneity }\end{array}$ & Direct & Imprecision & Likely & $\begin{array}{c}31.89(18.3- \\
76.5)\end{array}$ & 90.2 & Very low \\
\hline Amnioreduction & $30(4)$ & $\begin{array}{c}\text { Serious } \\
\text { limitations }\end{array}$ & $\begin{array}{l}\text { Unexplained } \\
\text { heterogeneity }\end{array}$ & Direct & Imprecision & Likely & $\begin{array}{c}25.88(11.0- \\
44.4)\end{array}$ & 7.9 & Very low \\
\hline \multicolumn{10}{|c|}{ Intact survival (overall) } \\
\hline Expectant & $17(3)$ & $\begin{array}{c}\text { Serious } \\
\text { limitations }\end{array}$ & $\begin{array}{l}\text { Unexplained } \\
\text { heterogeneity }\end{array}$ & Direct & Imprecision & Likely & $\begin{array}{c}44.37(14.7- \\
76.5)\end{array}$ & 52 & Very low \\
\hline Laser & $44(2)$ & $\begin{array}{c}\text { Serious } \\
\text { limitations }\end{array}$ & $\begin{array}{l}\text { Unexplained } \\
\text { heterogeneity }\end{array}$ & Direct & Imprecision & Likely & $\begin{array}{c}96.36(89.0- \\
99.8)\end{array}$ & 0 & Very low \\
\hline Amnioreduction & $16(3)$ & $\begin{array}{c}\text { Serious } \\
\text { limitations }\end{array}$ & $\begin{array}{l}\text { Unexplained } \\
\text { heterogeneity }\end{array}$ & Direct & Imprecision & Likely & $\begin{array}{c}77.97(56.2- \\
93.7)\end{array}$ & 0 & Very low \\
\hline
\end{tabular}



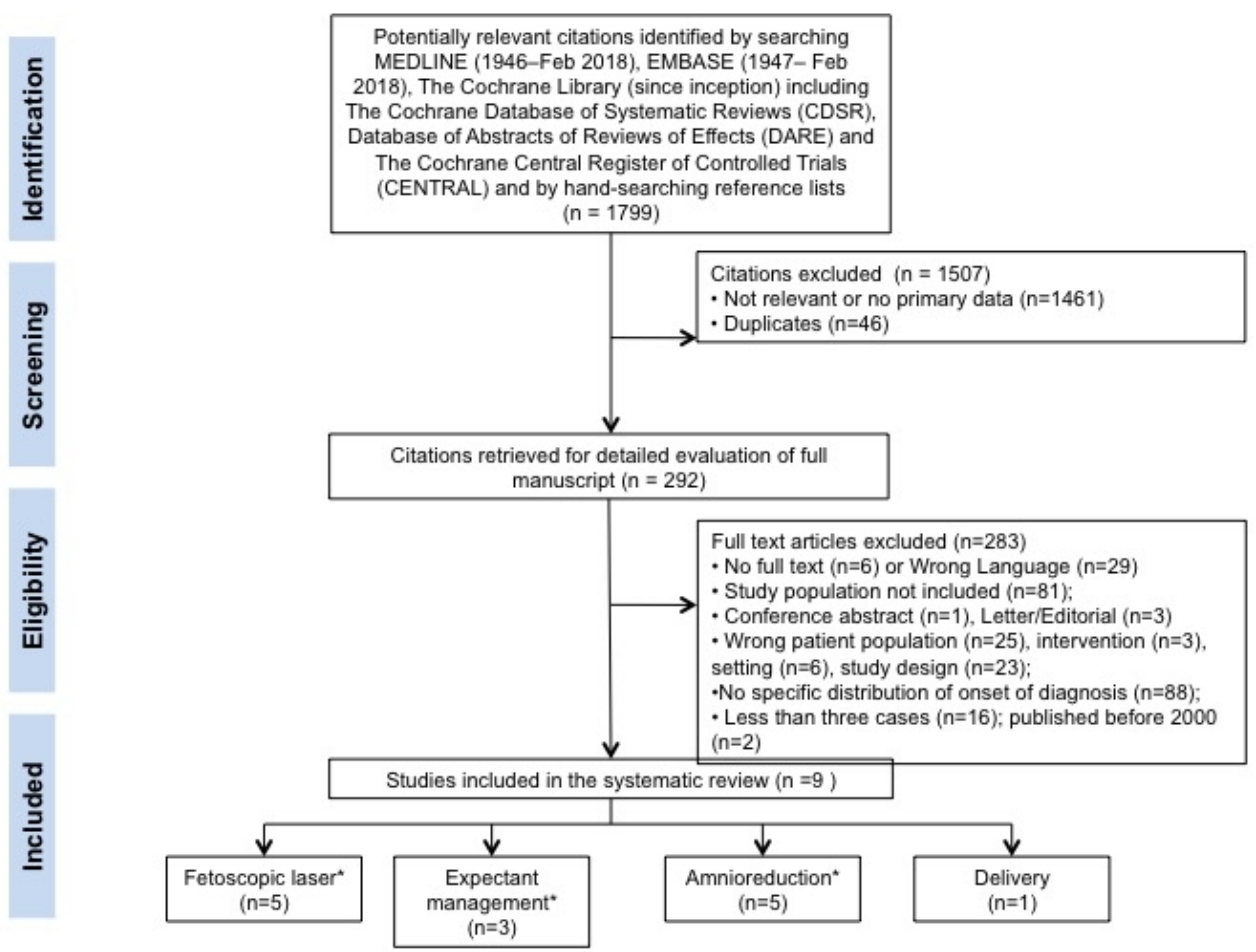

"Some studies reported on more than one management

aogs_14066_f1.jpg 